\title{
Demographic changes, educational improvements, and earnings in Brazil and Mexico
}

\author{
Ernesto F. L. Amaral ${ }^{1 *}$, Bernardo L. Queiroz ${ }^{2}$ and Júlia A. Calazans²
}

\author{
* Correspondence: \\ eamaral@rand.org \\ ${ }^{1}$ RAND Corporation, 1776 Main \\ Street, P.O. Box 2138, Santa Monica, \\ CA 90407-2138, USA \\ Full list of author information is \\ available at the end of the article
}

\begin{abstract}
This paper estimates the association of demographic and educational changes with earnings and returns to schooling of male workers in Brazil and Mexico. Our analysis takes into account demographic, educational, and economic variations within each country over time, using Demographic Censuses microdata from Brazil and Mexico. Results suggest that demographic and educational transitions are correlated with earnings and returns to education. Proportions of people in age-education groups tend to have negative associations with aggregated earnings. Workers with secondary education completed experience negative effects on their earnings by having lower education than university graduates (education effect) and by representing a bigger share of the population than males with university education completed (cohort size effect). The negative correlations of cohort size have been decreasing in magnitude over time. We also find that the concentration of skilled labor in specific locations has positive associations with individual earnings and that they are greater than those observed in more developed countries. Moreover, in Brazil and Mexico, these effects are observed throughout the income distribution, contrary to what is observed in studies for the United States.
\end{abstract}

JEL classification codes: 12 (Education economics), J1 (Demographic economics)

Keywords: Demographic transition, Education transition, Cohort size, Earnings, Labor Markets, Brazil, Mexico

\section{Introduction}

The objective of this paper is to estimate the association of demographic and educational changes with earnings of male workers in the two largest Latin American countries (Brazil and Mexico). Furthermore, we analyze the economic consequences of individuals with higher educational attainment (human capital) being concentrated within certain locations on the returns to schooling. The first exercise estimates the association of composition of the workforce by age and education with average earnings of workers. The second exercise looks on how the concentration of skilled workers correlates with returns to schooling (individual earnings) across regions of Brazil and Mexico. These two countries have very similar features and are passing through a rapid process of demographic and educational changes with large regional and social inequalities (Barro and Lee 2001; Lam and Marteleto 2005, 2008; Marcílio 2001, 2005; Potter et al. 2010; Potter et al. 2002; Riani 2005; Gong and Van Soest 2002; Lustig 
et al. 2013; Rios-Neto and Guimarães 2010). Our analysis takes into account demographic, educational and economic variations within each country and their regions over time. The study of wage differentials and the analysis of the effects of human capital concentration in developing countries are both important subjects to explore, since they are marked by larger economic differentials than developed countries.

The central advantage is that the concentration of well-educated people benefits everyone else in the population, as well as generates greater knowledge and economic dynamism. In the United States, the concentration of skilled people in some regions has a positive effects on productive gains, which further increases the concentration of qualified people in these areas (Berry and Glaeser 2005). The greatest concentration of skilled people in specific locations occurred in the 1980s and 1990s, leading to an increase in the wages of all workers (Moretti 2004a, Moretti 2004b, Moretti 2004c, Moretti 2011). The larger proportion of people with higher educational attainment benefits the population as a whole, as the result of a spillover effect (Moretti 2011; Hout 2012). Thus, there is a positive effect of population concentration on individual incomes (Moretti 2004a, Moretti 2004b, Moretti 2004c). Other studies indicate that there are positive effects on the economic dynamism of American cities resulting from the concentration of skilled workers (Black 1999; Rauch 1993).

There are numerous studies evaluating wage differentials and income concentration in several developing countries. However, there are few comparative studies of the dynamics that have recently been affecting local labor markets. Studies analyzed the concentration of human capital in Brazil (Queiroz and Golgher 2008), but they did not investigate the reasons or the implications of this concentration. Other studies emphasized positive effects of the concentration of skilled workers in the Brazilian labor market (Queiroz and Calazans 2010). However, variations in cohort size across municipalities in Brazil led to associations with workers' earnings (Amaral et al. 2013b; Amaral 2012; Amaral et al. 2013a; Amaral et al. 2012, 2016). More specifically, higher proportions of the population in age-education groups are negatively associated with income of these groups. These effects are larger for groups with higher educational attainment, but with declining effects over time. Thus, the concentration of skilled workers in specific locations can generate benefits for some groups, but can produce negative results for other groups.

This paper is part of a broader discussion of regional differences in income and economic growth. The following section of the paper presents our data and different methods strategies. We include explanations about how we estimated models to evaluate how earnings at the aggregate level are associated with the ageeducation composition of the workforce, i.e., correlations of large cohorts and earnings (Amaral et al. 2013b; Berger 1985; Biagi and Lucifora 2008; Brunello 2010; Easterlin 1978; Freeman 1979; Katz and Autor 1999; Katz and Murphy 1992; Korenman and Neumark 2000; Moretti 2004a, Moretti 2004b, Moretti 2004c; Sapozhnikov and Triest 2007; Shimer 2001; Skans 2005; Welch 1979). We also explain how we conducted an analysis about how the concentration of high-skilled workers in some parts of the country are associated with earnings at the individual level, known as social returns to education (Moretti 2011; Berry and Glaeser 2005). We then present the results of these two sets of exercises and provide some final considerations at the last section of the paper. 


\section{Data and methods}

We perform two exercises to investigate the associations of demographic and educational changes with earnings in the Brazilian and Mexican labor markets. The first exercise analyzes the correlations of the composition of the workforce by age and education with average earnings of workers. This analysis uses local-level data to construct ageeducation cells and follows their changes over time. The second study uses individual data to investigate how the concentration of skilled workers is associated with returns to schooling across regions of Brazil and Mexico. In the following sub-sections we present detailed information on the construction of the database and methods applied to investigate the two questions. We use microdata from the Brazilian and Mexican Demographic Censuses to estimate how population composition is correlated with earnings of male workers at the local level over time. Brazilian (1970-2010) and Mexican (1960-2010) data were obtained from IPUMS-International, Minnesota Population Center, University of Minnesota.

We categorized information on age into four groups: youths (15-24 years-ofage); young adults (25-34 years-of-age); experienced adults (35-49 years-of-age); and older adults (50-64 years-of-age). We also perform some analysis using data for those in the prime-age group, between 30 and 50 years old (results not shown). The level of education was classified into four groups using information on completed years of schooling and taking into account the specificities of the school systems in Brazil and Mexico. We utilize standardized variables created by IPUMS to compare both countries. IPUMS variables allow for international comparisons and focus on complete educational levels. The four education groups are: (a) less than primary education; (b) complete primary education and incomplete secondary; (c) complete secondary education and incomplete university; and (d) complete university education. These categories generated 16 age-education-group indicators, which are utilized throughout our analysis.

\subsection{Demographic changes and earnings}

We aggregate Census microdata by year, area, and age-education group. In relation to the geographical areas considered for this study, the 502 Brazilian micro-regions (groups of municipalities) have consistent boundaries over time. These 502 microregions differ from those defined by IBGE and available in the Census microdata, but closely approximate those that are defined in the 1991 Census (Potter et al. 2002). For Mexico, the geographical areas used for this study were 2456 municipalities, from 1990 to 2010. Mexican municipalities have consistent boundaries in our database only for these last three censuses. We also estimated models by the 32 Mexican states using all censuses, but due to the lack of data variation the results were not consistent (results not shown).

In order to measure the effect of demographic and educational transitions on earnings, the dependent variable is the natural logarithm of the mean monthly earnings for each year, area, and age-education group. In Brazil, information on earnings is based on primary occupation. In Mexico, information on earnings is based on earned income. For 1970, in both countries, information on earnings is based on total income, due to the lack of other available variables. 
In Equation (1), $\log \left(Y_{\text {git }}\right)$ is the logarithm of wages. Sixteen indicators of age-education groups $(G)$ interacting with time $(\theta)$ are included in the model. The first age-education group interacting with time is the reference category. $G_{g}$ is a set of age-education-group indicators (dichotomous variables) for the combinations of age and education groups. This procedure originates a vector of 15 parameters $\left(\beta_{1}\right)$ for each year, considering the first age-education group (15-24 years; less than primary completed) as the reference category. The model considers 502 micro-regions in Brazil and 2456 municipalities in Mexico ( $i$ ), five Brazilian Censuses and three Mexican Censuses $(t), 16$ age-education groups $(g)$, and $2510(502 * 5)$ area-time-fixed effects in Brazil and 7368 (2456*3) areatime-fixed effects in Mexico $(\alpha)$. An attempt to include interactions of age-educationgroup indicators with area-time-fixed effects was not successful, because this procedure reduces data variation and the statistical software informs that there is insufficient number of observations to estimate the model. Equation (1) can be expressed as follows:

$$
\log \left(Y_{g i t}\right)=\beta_{0}+\beta_{1} G_{g} * \theta_{t}+\alpha_{i t}+\varepsilon_{g i t} .
$$

Not only age and education have a significant association with earnings, but also demographic and educational changes generate variation in cohort size and, thus, influence various aspects of the labor market. As a strategy to estimate the correlations of cohort size with earnings, the distribution of the male population in our 16 ageeducation groups $(X)$, interacted with time $(\theta)$, can be introduced as a set of variables. This procedure originates a vector of 16 parameters $\left(\beta_{2}\right)$ for each year. This exercise is similar to a study that estimated the effects of immigration on the U.S. labor market (Borjas 2003). In our case, instead of including the immigration supply in the estimations, we include information on the male population distributed into age-education groups (g), in order to verify its associations with earnings:

$$
\log \left(Y_{g i t}\right)=\beta_{0}+\beta_{1} G_{g} * \theta_{t}+\beta_{2} X_{g} * \theta_{t}+\alpha_{i t}+\varepsilon_{g i t} .
$$

Because Brazil was divided into 502 micro-regions, 16 age-education groups, and five censuses, the maximum possible number of observations for the regressions is 40,160 and the maximum number of groups (area-time fixed effects) is 2510. However, only cells with at least 25 observations are included in the estimations, in order to minimize potential problems of heteroskedasticity. The aggregated database utilized the census weights to estimate mean earnings and proportional distributions of males by ageeducation group, time, and area. We did also reweight the regressions by population size and the results are similar to the ones presented in this paper, as it was also verified by Amaral et al. (2013b). The maximum number of observations was reduced to 32,201 and the number of groups to 2488. In Mexico, we used 2456 municipalities, which would generate a maximum of $117,888(2456 * 16 * 3)$ observations and 7368 groups for the regressions. Due to our cell-size criteria, the number of observations was reduced to 82,604 and the number of groups to 7259 .

\subsection{Human capital concentration and returns to education}

We estimate the association of concentration of human capital with individual earnings using quantile regressions models. We utilize these regression models because they produce different effects along the distribution of the dependent variable instead of estimating the model with average effects. In other words, they look at heterogeneity on 
the conditional distribution instead of the average (Martins and Pereira 2004; Despa 2007). Our hypothesis is that the private and social returns to education vary due to the socioeconomic position of workers in their place of residence. The basic model on the social returns to education has the premise that personal investment in education and training create benefits for other agents in the economy, both to the more skilled and to less skilled (Acemoglu 1996). By investing in human capital individuals become more productive and relate to other employees in the workplace and elsewhere, due to their capacity of transmitting new knowledge and skills to others (Acemoglu 1996). The model to estimate social returns to education is:

$$
\log \left(Y_{\text {git }}\right)=\beta_{0}+\beta_{1} X \varepsilon_{\text {git }} \text {, with } \operatorname{Quant}_{\emptyset}(y i \mid x i)=\beta_{0}+\beta_{1} X \varepsilon_{\text {git }}
$$

where $\log \left(Y_{\text {git }}\right)$ is the logarithm of individual earnings. The main variable of interest is the proportion of workers with university level that captures social returns to education. We add age-education group controls, as in the first exercise. These variables capture the private returns to education controlling for years of experience. We also include variables to capture labor demand, measured by local level unemployment rate in the region. Regional characteristics are captured by a series of dummy variables for regions in each country and urbanization rate in each census year. Regions in each country are characterized following the suggestions of the national statistical offices in Brazil and Mexico. Equation (3) is estimated to the overall 15-64 male population in each country and year (2000 and 2010), as well as by quantiles defined by level of earnings (dependent variable): (1) up to 25th percentile; (2) up to 50th percentile; and (3) above 75th percentile.

The spatial distribution of human capital is associated with unobserved factors that can be correlated with the level of income, so the local educational level becomes endogenous in the model. In order to attempt to solve for this limitation, we also estimated the concentration of highly skilled workers through an instrumental variable approach (results not shown). We used education progression rates and age composition of the population to estimate the concentration of educated workers in the current census (Moretti 2004a, Moretti 2004b, Moretti 2004c). Age composition is normally used in the literature as an instrument for the proportion of educated individuals in one region (Moretti 2004a, Moretti 2004b, Moretti 2004c). Moretti (2004a) uses the presence of a land-grant college in a region as a second instrumental variable in the model. He argues that those are related to the presence of college-educated workers, but are not related to the current labor market conditions. In our case, we do not have similar information as land granted college. We proposed education progression rates as a measure to capture the quality and investment in education by region, but we assume that they are not correlated to current labor market conditions. We used all instruments lagged to the previous census year. The proportion of high-skilled workers is defined by the following equation:

$$
P_{(t)}=\beta_{0}+\beta_{1} L_{1(t-n)}+\beta_{2} L_{2(t-n)}++\varepsilon_{(t)},
$$

where $P_{(t)}$ is the proportion of workers with high educational level (proportion of undergraduates) in time $t$ for each investigated area; $L_{1(t-n)}$ is the enrolment rate in high school in the previous census, $n$ years ago; and $L_{2(t-n)}$ is the young-age-dependency ratio in the previous census. We estimated the Durbin-Wu-Hausman test to the models that utilized these instruments. Results indicate that our instruments were not capable 
to control for endogeneity of regional concentration of human capital. Education progression rates and age composition were not sufficient to correct this problem in the estimated models. Thus, we focus on the basic models using the observed proportion of educated workers by region, which is Equation (3) without instruments. We cannot obtain a causal effect, but the results indicate long-term associations of the concentration of qualified workers in different regions of the country.

\section{Results}

\subsection{Demographic changes and earnings}

The estimation of an income equation is central to assess the association between an aging population and educational changes with average income. This analysis seeks to establish whether changes in age and education structures influenced income in Brazil and Mexico. Before estimating the models, it is important to evaluate the distribution of the male population by year and age-education group in the countries (Tables 1 and 2). In general, the proportion of men with less than primary completed decreased between 1970 and 2010 in Brazil. For example, the proportion between 15-24 years of age with less than primary completed fell considerably from $32.34 \%$ in 1970 to $9.53 \%$ in 2010 in Brazil (Table 1). This trend is also observed for the other age groups. The same happened in Mexico for males in this age-education group, with a decrease from $20.75 \%$ in 1970 to $1.75 \%$ in 2010 (Table 2). In addition, the proportion of those with secondary completed and university completed in Brazil and Mexico increased during the period in all age groups.

Table 1 Male population distributed into particular age-education groups, as percentage shares, Brazil, 1970-2010

\begin{tabular}{lrrrrr}
\hline Age-education groups & 1970 & 1980 & 1991 & 2000 & 2010 \\
\hline 15-24 years; less than primary completed & 32.34 & 27.15 & 23.32 & 17.43 & 9.53 \\
15-24 years; primary completed & 2.56 & 6.18 & 5.95 & 8.84 & 9.32 \\
15-24 years; secondary completed & 1.32 & 3.01 & 3.17 & 5.22 & 7.59 \\
15-24 years; university completed & 0.09 & 0.18 & 0.24 & 0.25 & 0.40 \\
25-34 years; less than primary completed & 20.86 & 18.58 & 16.32 & 13.71 & 8.92 \\
25-34 years; primary completed & 1.15 & 2.51 & 4.16 & 4.25 & 4.78 \\
25-34 years; secondary completed & 1.14 & 2.80 & 4.65 & 5.28 & 9.27 \\
25-34 years; university completed & 0.55 & 1.25 & 1.51 & 1.32 & 2.35 \\
35-49 years; less than primary completed & 23.46 & 20.37 & 18.82 & 17.12 & 14.45 \\
35-49 years; primary completed & 0.97 & 1.54 & 2.50 & 4.08 & 4.89 \\
35-49 years; secondary completed & 0.82 & 1.47 & 2.97 & 5.07 & 7.38 \\
35-49 years; university completed & 0.62 & 1.06 & 2.02 & 2.23 & 2.68 \\
50-64 years; less than primary completed & 13.10 & 12.28 & 11.96 & 11.33 & 11.07 \\
50-64 years; primary completed & 0.43 & 0.65 & 0.81 & 1.28 & 2.40 \\
50-64 years; secondary completed & 0.28 & 0.54 & 0.89 & 1.49 & 3.19 \\
50-64 years; university completed & 0.31 & 0.44 & 0.72 & 1.10 & 1.78 \\
Total & 100.00 & 100.00 & 100.00 & 100.00 & 100.00 \\
Sample size (n) & $6,772,670$ & $7,895,865$ & $4,992,270$ & $6,287,104$ & $6,721,044$ \\
Population size (N) & $25,760,594$ & $31,848,780$ & $43,434,534$ & $53,177,963$ & $62,707,571$ \\
\hline 1970 $1980,1991,2000,5$ & and 2010 Bran
\end{tabular}

1970, 1980, 1991, 2000, and 2010 Brazilian Demographic Censuses (Brazilian Institute of Geography and Statistics - IBGE) 
Table 2 Male population distributed into particular age-education groups, as percentage shares, Mexico, 1960-2010

\begin{tabular}{|c|c|c|c|c|c|}
\hline Age-education groups & 1960 & 1970 & 1990 & 2000 & 2010 \\
\hline 15-24 years; less than primary completed & 26.53 & 20.75 & 6.66 & 3.78 & 1.75 \\
\hline 15-24 years; primary completed & 8.88 & 15.02 & 25.78 & 23.14 & 20.14 \\
\hline 15-24 years; secondary completed & 0.56 & 1.03 & 4.86 & 5.43 & 6.97 \\
\hline 15-24 years; university completed & 0.08 & 0.34 & 0.65 & 0.82 & 0.97 \\
\hline 25-34 years; less than primary completed & 19.68 & 16.72 & 6.78 & 3.82 & 2.50 \\
\hline 25-34 years; primary completed & 4.43 & 6.09 & 11.88 & 14.31 & 12.05 \\
\hline 25-34 years; secondary completed & 0.43 & 0.58 & 3.67 & 4.81 & 5.35 \\
\hline 25-34 years; university completed & 0.27 & 0.82 & 2.82 & 3.08 & 3.59 \\
\hline 35-49 years; less than primary completed & 20.23 & 19.57 & 11.02 & 7.32 & 4.80 \\
\hline 35-49 years; primary completed & 3.90 & 4.96 & 9.00 & 11.95 & 14.82 \\
\hline 35-49 years; secondary completed & 0.37 & 0.38 & 1.91 & 3.73 & 5.67 \\
\hline 35-49 years; university completed & 0.28 & 0.66 & 2.14 & 3.89 & 4.14 \\
\hline 50-64 years; less than primary completed & 12.24 & 10.52 & 8.45 & 7.14 & 5.80 \\
\hline 50-64 years; primary completed & 1.84 & 2.21 & 3.31 & 4.60 & 6.99 \\
\hline 50-64 years; secondary completed & 0.15 & 0.19 & 0.56 & 0.98 & 2.08 \\
\hline 50-64 years; university completed & 0.12 & 0.26 & 0.53 & 1.21 & 2.37 \\
\hline Total & 100.00 & 100.00 & 100.00 & 100.00 & 100.00 \\
\hline Sample size (n) & 126,959 & 118,679 & $2,235,704$ & $2,742,731$ & $3,446,157$ \\
\hline Population size (N) & $8,506,253$ & $11,867,900$ & $22,357,040$ & $27,403,338$ & $34,401,639$ \\
\hline
\end{tabular}

1960, 1970, 1990, 2000, and 2010 Mexican Demographic Censuses (IPUMS-International)

Equation (1) - the baseline model - interacts the indicator variables for ageeducation groups with each Census year. In Tables 3 (Brazil) and 4 (Mexico), we present the exponential of coefficients from this equation, related to the correlation between age-education groups and earnings. Here as in the subsequent estimates, the coefficients of area-time fixed effects are highly significant statistically. The numbers in the first column are the exponential of coefficients related to the correlation between age-education groups and earnings for 1970 (main effects). The exponentials in the other columns take into account the 1970 main effects interacted with each additional year. All coefficients are statistically significant at $p<$ 0.01. In general, within each age category, earnings are higher for those people with more schooling. We also verify that within each education group, earnings are higher for older men. For instance, in Brazil (Table 3) men ages 25-34 with less than primary completed earned 1.44 times as much as men ages 15-24 with the same education (the reference category) in 1970. In 2010, young men (25-34) with university completed earned 4.6 times as much as the reference category. For Mexico (Table 4), the results follow the same pattern and all coefficients are statistically significant at $p<0.01$. For example, men ages $25-34$ with less than primary completed earned 1.12 times as much as men ages 15-24 with the same education in 1990. In 2010, young men (25-34) with university completed earned 2.72 times as much as the reference category. The estimates are thus consistent with what we know about age-earnings profiles and the association of education on them (Mincer 1974; Hamermesh 1993). 
Table 3 Exponential of coefficients estimated with area-time fixed-effects from Equation (1) for the logarithm of mean real monthly earnings from main occupation as the dependent variable, Brazil, 1970-2010

\begin{tabular}{|c|c|c|c|c|c|}
\hline Age-education indicators & 1970 & 1980 & 1991 & 2000 & 2010 \\
\hline $\begin{array}{l}5-24 \text { years; less than primary } \\
\text { ompleted (reference group) }\end{array}$ & 0 & 0 & 0 & 1. & 1.000 \\
\hline $15-24 y$ & $2.130(0.028)$ & $1.571(0.019)$ & $1.519(0.019)$ & $1.242(0.015)$ & $1.110(0.014)$ \\
\hline 15-24 years; secondary completed & $3.184(0.050)$ & $2.553(0.034)$ & $2.197(0.028)$ & $1.845(0.023)$ & $1.511(0.019)$ \\
\hline 15-24 years; university completed & $6.069(0.203)$ & $4.522(0.109)$ & $3.590(0.090)$ & $3.546(0.077)$ & $2.596(0.043)$ \\
\hline $\begin{array}{l}\text {-34 years; less than } \\
\text { imary completed }\end{array}$ & $1.438(C$ & $1.584(C$ & 1.470 & $1.504(0.018)$ & $1.337(0.017)$ \\
\hline -34 years; primary completed & $4.081(0.061)$ & $3.301(0.042)$ & $2.674(0.033)$ & $2.492(0.031)$ & $1.689(0.021)$ \\
\hline 5-34 years; secondary completed & $5.480(0.087)$ & $4.728(0.062)$ & $3.973(0.050)$ & $3.488(0.043)$ & $2.250(0.028)$ \\
\hline completed & 10.7 & 8.66 & 7 & 6 & 4.5 \\
\hline $\begin{array}{l}35-49 \text { years; less than } \\
\text { orimary completed }\end{array}$ & $1.707(0.021)$ & $1.952(0.024)$ & $1.866(0.023)$ & $1.882(0.023)$ & $1.548(0.019)$ \\
\hline -49 years; primary completed & $6.000(0.100)$ & $5.161(0.072)$ & $4.053(0.053)$ & $3.624(0.045)$ & $2.350(0.029)$ \\
\hline 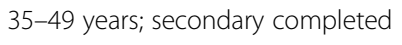 & $7.923(0.138)$ & 7.08 & 1) & 5.7 & $3.420(0.042)$ \\
\hline 5-49 years; university completed & $13.348(0.259)$ & $11.407(0.185)$ & $10.701(0.161)$ & $11.068(0.155)$ & $6.798(0.088)$ \\
\hline $\begin{array}{l}\text {-64 years; less than primary } \\
\text { mpleted }\end{array}$ & $1.702(0.021)$ & $1.916(0.023)$ & $1.816(0.022)$ & $1.987(0.024)$ & $1.630(0.020)$ \\
\hline 50-64 years; primary completed & $6.620(0.135)$ & $5.883(0.100)$ & $4.923(0.083)$ & $4.446(0.061)$ & $2.758(0.035)$ \\
\hline -64 years; secondary completed & $8.483(0.203)$ & $8.048(0.148)$ & $7.211(0.125)$ & $7.150(0.101)$ & $4.331(0.055)$ \\
\hline 50-64 years; university completed & $12.929(0.312)$ & $11.783(0.249)$ & $11.576(0.223)$ & $12.798(0.206)$ & $8.939(0.124)$ \\
\hline
\end{tabular}

All coefficients are significant at $p<0.01$. The numbers in the first column are the exponential of coefficients related to the correlation between age-education groups and earnings for 1970 (main effects). The exponentials in the other columns take into account the 1970 main effects interacted with each additional year, using linear combinations of estimators in Stata (command "lincom"). Standard errors are reported in parentheses

1970, 1980, 1991, 2000, and 2010 Brazilian Demographic Censuses (Brazilian Institute of Geography and Statistics - IBGE)

Equation (2) has similar results to Equation (1), in relation to the coefficients of ageeducation group indicators (binary variables) and area-time fixed effects. The important analysis from this second model concerns the variables related to the proportion of males in each age-education group in the workforce as independent variables (cohort size, relative supply, labor supply, cell density, or own-quantity effects), and allows them to vary over time by interacting these proportions with Census years (time indicators). In order to better understand the estimates, we calculate elasticities to demonstrate the association between age-education proportions and earnings. Figure 1 (for Brazil) and Fig. 2 (for Mexico) present elasticities that were calculated as the product of age-education-proportions coefficients and the national distribution of men by ageeducation groups over time (Tables 1 and 2). More specifically, the elasticities were estimated using this expression: (exp(coefficient of proportion in an age-education group*distribution of men by age-education group*0.01)-1)*100. For more recent years (interaction terms), the main effect coefficient (1970 in Brazil and 1990 in Mexico) was added to the interaction term for each Census, before multiplying by the distribution of men by age-education groups and year.

In Brazil (Fig. 1), among all age-education groups (besides the less than primary completed), there are negative correlations between group size and earnings in the earliest period. The estimated elasticities in 1970 for the proportions of men in each age- 
Table 4 Exponential of coefficients estimated with area-time fixed-effects from Equation (1) for the logarithm of mean nominal monthly earnings from main occupation as the dependent variable, Mexico, 1990-2010

\begin{tabular}{llll}
\hline Age-education indicators & 1990 & 2000 & 2010 \\
\hline $\begin{array}{l}\text { 15-24 years; less than primary completed } \\
\text { (reference group) }\end{array}$ & 1.000 & 1.000 & 1.000 \\
15-24 years; primary completed & $1.165(0.015)$ & $1.120(0.014)$ & $1.134(0.014)$ \\
15-24 years; secondary completed & $1.390(0.020)$ & $1.409(0.019)$ & $1.340(0.017)$ \\
15-24 years; university completed & $1.609(0.044)$ & $1.943(0.052)$ & $1.856(0.049)$ \\
25-34 years; less than primary completed & $1.121(0.015)$ & $1.115(0.014)$ & $1.155(0.015)$ \\
25-34 years; primary completed & $1.465(0.019)$ & $1.412(0.018)$ & $1.382(0.017)$ \\
25-34 years; secondary completed & $1.821(0.026)$ & $2.157(0.030)$ & $1.837(0.025)$ \\
25-34 years; university completed & $2.314(0.040)$ & $3.256(0.054)$ & $2.722(0.045)$ \\
35-49 years; less than primary completed & $1.214(0.016)$ & $1.168(0.015)$ & $1.183(0.015)$ \\
35-49 years; primary completed & $1.598(0.021)$ & $1.548(0.020)$ & $1.496(0.019)$ \\
35-49 years; secondary completed & $2.099(0.033)$ & $2.731(0.039)$ & $2.293(0.033)$ \\
35-49 years; university completed & $2.776(0.049)$ & $4.305(0.071)$ & $3.659(0.060)$ \\
50-64 years; less than primary completed & $1.069(0.014)$ & $1.047(0.013)$ & $1.065(0.013)$ \\
50-64 years; primary completed & $1.427(0.020)$ & $1.493(0.019)$ & $1.474(0.019)$ \\
50-64 years; secondary completed & $2.413(0.058)$ & $2.808(0.063)$ & $2.513(0.056)$ \\
50-64 years; university completed & $3.406(0.092)$ & $4.806(0.120)$ & $4.391(0.109)$ \\
\hline All cofficis
\end{tabular}

All coefficients are significant at $p<0.01$. The numbers in the first column are the exponential of coefficients related to the correlation between age-education groups and earnings for 1990 (main effects). The exponentials in the other columns take into account the 1990 main effects interacted with each additional year, using linear combinations of estimators in Stata (command "lincom"). Standard errors are reported in parentheses 1990, 2000, and 2010 Mexican Demographic Censuses (IPUMS-International)

education group generally indicate greater negative correlations for workers with primary completed or secondary completed. These negative effects are offset by the positive interactions throughout time for men up to 49 years of age, increasing the elasticities through time. Indeed, by 2010 the coefficients on the interaction terms nearly offset the negative coefficients of the main effect terms, so that in the more educated groups the net correlation of a change in the group proportions with earnings was much reduced. For men in the first three age groups (15-24, 25-34 and 35-49 years) with less than primary completed, the group proportions have positive correlations with earnings in 1970 and they become negative over time. Mexico (Fig. 2) has much weaker elasticities than Brazil in terms of magnitude. In the earliest period (1990) in Mexico, the greatest negative correlations between age-education-group proportions and earnings are observed for younger men (15-24 and 25-34) with secondary completed and older men (35-49 and 50-64) with less than primary completed. Proportions in age-education groups tend to have positive correlations with earnings among men with primary completed or university completed, but these correlations decrease over time.

Among men with less than primary completed in Brazil (Fig. 1), the elasticities start positive for younger groups and become negative over time, with great variation for 15-24 year-old men. For 50-64 year-old men within this education group, negative elasticities were observed in 1970 and 1980, increased over time and dropped again by 2010 (but they are not statistically significant in 2000 and 2010). These results mean 

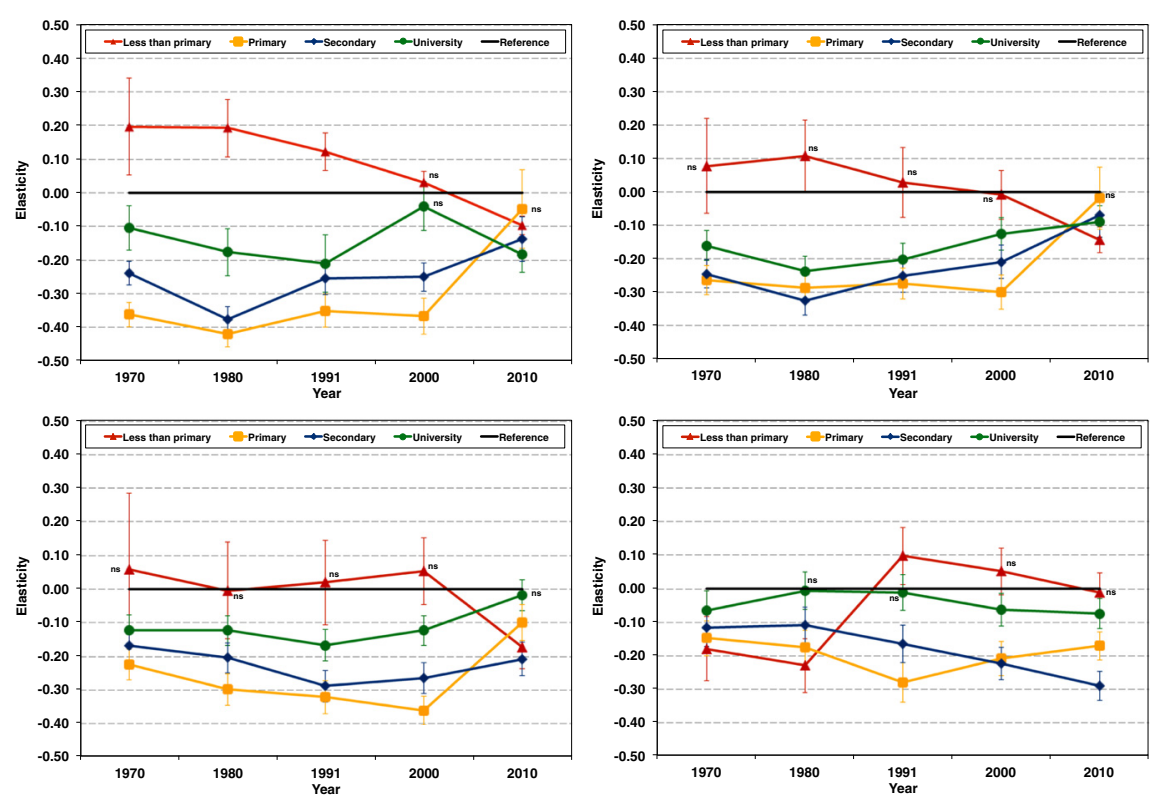

Fig. 1 Effects of proportion of male working-age population by age-education groups (factor-price elasticities) and 90 percent confidence interval on mean real monthly earnings from main occupation (dependent variable), based on Equation (2), using the national age-education distribution (Table 1), Brazil, 1970-2010. Note: ${ }^{\text {ns }}$ Non-significant. All other coefficients are significant at least at $p<0.1$. Statistical significance was estimated with linear combinations of estimators in Stata (command "lincom"), taking into account the 1970 main effects interacted with each additional year. Sources: 1970, 1980, 1991, 2000, and 2010 Brazilian Demographic Censuses (Brazilian Institute of Geography and Statistics IBGE)

that the proportions of the least-educated men have negative correlations with their earnings in recent years, even with lower shares in the population. These estimates might suggest that the Brazilian labor market does not require as many low educated men in recent years, as it did in previous decades. Within each age group in 1970, Fig. 1 shows that elasticities are more negative among males with primary completed or secondary completed, when these groups represented a lower percentage in the overall population (Table 1). The elasticities of men with primary, secondary, or university completed tend to become less negative over time. An exception is for older men (50-64 age group) with secondary completed, which still represents a small share of the Brazilian population in 2010 (3.19\% in Table 1). For instance, an increase of ten percent of males with 15-24 years of age and secondary completed is correlated to $2.4 \%(-0.24)$ decrease in earnings in 1970 and 1.4\% decrease in 2010. Among young men (25-34) with secondary completed the association with earnings changes from $-2.5 \%$ in 1970 to $-0.7 \%$ in 2010 for an increase of ten percent in the group. An increase of ten percent in the number of men with 25-34 years and university completed is associated with $1.6 \%$ decrease in earnings in 1970 and $0.9 \%$ decrease in 2010. Among 35-49 year-old men with university completed, an increase of ten percent in the group is negatively associated with their earnings by $1.2 \%$ in 1970 . By 2010 , the negative correlation in this age-education group (only $-0.2 \%$ for an increase of ten percent in the group size) is not statistically significant. These results are an indication that local labor 


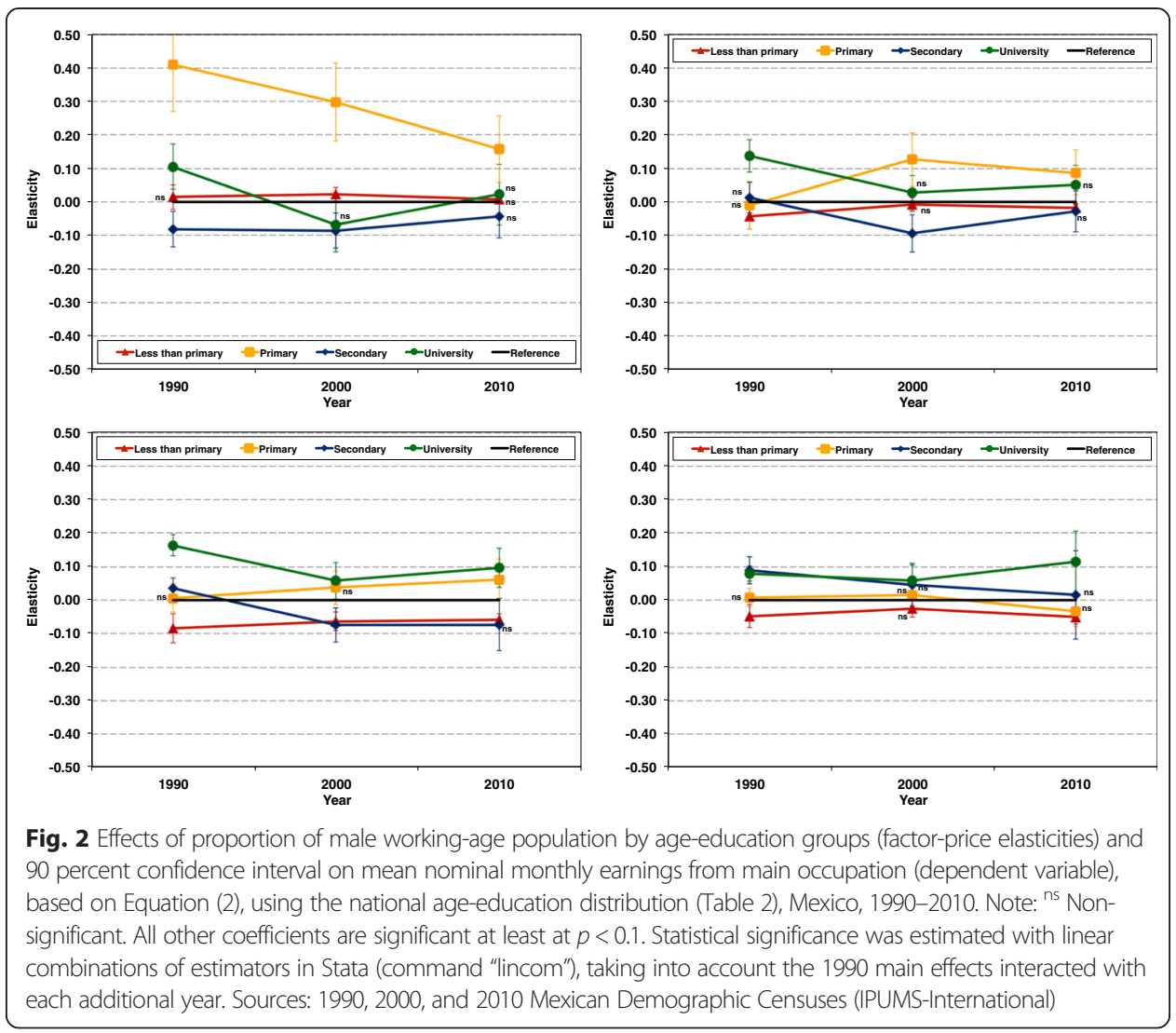

markets are absorbing higher proportions of men in groups with secondary and university completed in recent years, without strong negative correlations with their earnings.

The Mexican estimates (Fig. 2) have smaller magnitudes than the Brazilian elasticities (Fig. 1). Elasticities in Mexico indicate that relative changes in labor supply (group proportions) have been having less of a correlation with relative wages than they did at the start of our sample period. In 1990 among younger Mexicans (15-24 and 25-34 age groups), the elasticities of those with secondary completed present the strongest negative correlations with earnings. However, these negative associations are less pronounced in 2010. The elasticities of 15-24 year-old men with primary completed become much less positive over time. For older groups (35-49 and 50-64 age groups) with less than primary completed, the negative elasticities may be an indicative of low demand for labor without education. Among all groups in 2010, the only elasticities with negative correlations of at least -0.05 are for men ages 35-49 with less than primary completed $(-0.06), 35-49$ with secondary completed $(-0.07)$, and $50-64$ with less than primary completed $(-0.05)$. In all age groups with university completed, elasticities increased between 2000 and 2010 and present a positive sign by the end of the period, but they are not statistically significant for 15-24 and 25-34 year-old men. Some of the reasons for these positive correlations of the size of the highest educational attainment groups might be technological shifts and increasing demand for skilled labor. 


\subsection{Human capital concentration and returns to education}

Tables 5 and 6 show the results of the association of human capital concentration with individual earnings. In the case of Brazil and Mexico, university graduates receive higher income than those with less than primary education. For instance, we find that older Brazilian workers (50-64) with university completed earn 2.45 times as much as men ages 15-24 with less than primary completed (reference category) in 2000 (Table 5). In Mexico, older workers with university completed receive, on average, 1.66 as much as the reference category in 2000 (Table 6). For all age groups, we find similar results in both countries, but the magnitude of the coefficients is much smaller in Mexico than in Brazil. In both countries, as observed in the previous analysis, the returns to education compared to young adults with less than primary education have declined from 2000 to 2010 .

The concentration of workers with university degree in Brazil and Mexico has a positive association with individuals' earnings across the income distribution (Tables 5 and 6). In Mexico, results indicate that these effects are rising over time: a ten percent increase in the proportion of university graduates is related to $0.06 \%$ (0.0058 in Table 6) increase in earnings in 2000 and $0.08 \%$ increase in 2010. In Brazil (Table 5), we also find positive correlations of the concentration of university graduates with earnings, but these effects have declined substantially between $2000(0.16 \%)$ and $2010(0.08 \%)$. This reduction might be related to the education progress that Brazil has observed in recent periods, which might smooth the correlation between concentration of university graduates and individual levels. Figure 3 summarizes the coefficients estimated for the social returns to education across earnings levels from Tables 5 and 6 . The effects increase along the earnings distribution. Wealthier workers in Brazil (third quantile) benefit more from the concentration of university graduates than those in the lowest quantile. These differentials are more pronounced in 2010 than in 2000. In Mexico, there is not much difference across the income distribution in 2010, compared to bigger variations across quantiles in 2000. Thus we find that concentration of human capital in 2010 has greater associations with earnings in Mexico than in Brazil, but these effects vary more across the income distribution in Brazil than in Mexico.

Our main hypothesis is that the labor force in Brazil is more evenly distributed in the territory compared to Mexico. As a result, in Brazil there is a "shortage" of skilled labor across the country. Workers are complementary in the labor market and generate positive externalities, especially among wealthier and more educated. We assume that complementary workers are those with different skills that create benefits to other individuals in the labor market or in the firm. They cannot easily substitute one another and to improve productivity it is important to have both workers in the same sector. In Mexico, as the markets are more concentrated, competition is greater. Mexican wealthier workers have a degree of substitution, that is, firms can easily find replacements for other workers what creates more completion for positions in the labor market and reduce the gains to education. As a consequence, the effects of human capital concentration in Mexico are not as unequal as in Brazil, even though both countries have high levels of income inequality. 
Table 5 Coefficients and standard errors estimated with model from Equation (3) for the logarithm of individual earnings as the dependent variable by income quantile, Brazil, 2000 and 2010

\begin{tabular}{|c|c|c|c|c|c|c|c|c|}
\hline \multirow[t]{2}{*}{ Independent variables } & \multicolumn{4}{|l|}{2000} & \multicolumn{4}{|l|}{2010} \\
\hline & Total & $\begin{array}{l}1 \text { quantile (up to } \\
25 \text { th percentile) }\end{array}$ & $\begin{array}{l}2 \text { quantile (up to } \\
50 \text { th percentile) }\end{array}$ & $\begin{array}{l}3 \text { quantile (above } \\
\text { 75th percentile) }\end{array}$ & Total & $\begin{array}{l}1 \text { quantile (up to } \\
\text { 25th percentile) }\end{array}$ & $\begin{array}{l}2 \text { quantile (up to } \\
50 \text { th percentile) }\end{array}$ & $\begin{array}{l}3 \text { quantile (above } \\
75 \text { th percentile) }\end{array}$ \\
\hline \multicolumn{9}{|c|}{ Age-education groups - reference: $15-24$ years; less than primary completed } \\
\hline $\begin{array}{l}15-24 \text { years; primary } \\
\text { completed }\end{array}$ & $0.1224(0.0025)$ & $0.0833(0.0007)$ & $0.0835(0.0012)$ & $0.0945(0.0026)$ & $0.1312(0.0032)$ & $0.2210(0.0007)$ & $0.0834(0.0020)$ & $0.0674(0.0021)$ \\
\hline $\begin{array}{l}15-24 \text { years; secondary } \\
\text { completed }\end{array}$ & $0.5658(0.0030)$ & $0.4646(0.0008)$ & $0.4637(0.0014)$ & $0.5763(0.0032)$ & $0.4506(0.0033)$ & $0.4586(0.0008)$ & $0.2958(0.0021)$ & $0.3007(0.0022)$ \\
\hline $\begin{array}{l}\text { 15-24 years; university } \\
\text { completed }\end{array}$ & $1.3589(0.0117)$ & $1.1718(0.0034)$ & $1.3188(0.0059)$ & $1.4808(0.0134)$ & $0.9391(0.0065)$ & $0.7481(0.0017)$ & $0.7272(0.0045)$ & $0.9049(0.0047)$ \\
\hline $\begin{array}{l}25-34 \text { years; less than } \\
\text { primary completed }\end{array}$ & $0.3425(0.0023)$ & $0.2754(0.0006)$ & $0.2868(0.0011)$ & $0.3199(0.0024)$ & $0.3028(0.0034)$ & $0.3290(0.0008)$ & $0.2046(0.0021)$ & $0.2192(0.0022)$ \\
\hline $\begin{array}{l}25-34 \text { years; primary } \\
\text { completed }\end{array}$ & $0.6958(0.0026)$ & $0.5843(0.0007)$ & $0.6057(0.0012)$ & $0.6954(0.0028)$ & $0.5097(0.0032)$ & $0.5132(0.0008)$ & $0.3726(0.0020)$ & $0.3844(0.0021)$ \\
\hline $\begin{array}{l}25-34 \text { years; secondary } \\
\text { completed }\end{array}$ & $1.1181(0.0027)$ & $0.9272(0.0008)$ & $1.0342(0.0013)$ & $1.1829(0.0030)$ & $0.7876(0.0032)$ & $0.6957(0.0007)$ & $0.5833(0.0020)$ & $0.7065(0.0021)$ \\
\hline $\begin{array}{l}25-34 \text { years; university } \\
\text { completed }\end{array}$ & $1.8978(0.0045)$ & $1.6817(0.0013)$ & $1.8639(0.0022)$ & $2.0700(0.0051)$ & $1.5420(0.0038)$ & $1.2573(0.0010)$ & $1.3393(0.0026)$ & $1.5741(0.0027)$ \\
\hline $\begin{array}{l}35-49 \text { years; less than } \\
\text { primary completed }\end{array}$ & $0.4903(0.0022)$ & $0.3412(0.0006)$ & $0.3966(0.0010)$ & $0.5089(0.0023)$ & $0.4184(0.0032)$ & $0.3860(0.0007)$ & $0.2747(0.0020)$ & $0.3301(0.0020)$ \\
\hline $\begin{array}{l}35-49 \text { years; primary } \\
\text { completed }\end{array}$ & $0.9319(0.0026)$ & $0.7523(0.0007)$ & $0.8360(0.0012)$ & $0.9957(0.0028)$ & $0.7065(0.0032)$ & $0.6077(0.0007)$ & $0.5343(0.0020)$ & $0.6442(0.0021)$ \\
\hline $\begin{array}{l}35-49 \text { years; secondary } \\
\text { completed }\end{array}$ & $1.4889(0.0027)$ & $1.2223(0.0008)$ & $1.3984(0.0013)$ & $1.6570(0.0030)$ & $1.0756(0.0032)$ & $0.8954(0.0008)$ & $0.8768(0.0021)$ & $1.0839(0.0022)$ \\
\hline $\begin{array}{l}\text { 35-49 years; university } \\
\text { completed }\end{array}$ & $2.3119(0.0036)$ & $2.0740(0.0010)$ & $2.2874(0.0018)$ & $2.5012(0.0040)$ & $1.9550(0.0037)$ & 1.6217 (0.0009) & $1.7494(0.0025)$ & $2.0157(0.0026)$ \\
\hline $\begin{array}{l}\text { 50-64 years; less than } \\
\text { primary completed }\end{array}$ & $0.4640(0.0025)$ & $0.2628(0.0006)$ & $0.3441(0.0011)$ & $0.5167(0.0026)$ & $0.4466(0.0033)$ & $0.3602(0.0008)$ & $0.2757(0.0021)$ & $0.3709(0.0021)$ \\
\hline
\end{tabular}


Table 5 Coefficients and standard errors estimated with model from Equation (3) for the logarithm of individual earnings as the dependent variable by income quantile, Brazil, 2000 and 2010 (Continued)

\begin{tabular}{|c|c|c|c|c|c|c|c|c|}
\hline $\begin{array}{l}\text { 50-64 years; } \\
\text { primary completed }\end{array}$ & $1.0481(0.0045)$ & $0.7674(0.0013)$ & $0.9301(0.0022)$ & $1.1954(0.0050)$ & $0.7812(0.0037)$ & $0.6006(0.0009)$ & $0.5782(0.0024)$ & $0.7707(0.0025)$ \\
\hline $\begin{array}{l}\text { 50-64 years; secondary } \\
\text { completed }\end{array}$ & 1.6039 (0.0049) & $1.2459(0.0014)$ & $1.5197(0.0024)$ & $1.8590(0.0055)$ & $1.2253(0.0038)$ & $0.9403(0.0010)$ & $1.0348(0.0026)$ & $1.3139(0.0027)$ \\
\hline $\begin{array}{l}\text { 50-64 years; university } \\
\text { completed }\end{array}$ & $2.4520(0.0051)$ & $2.1785(0.0015)$ & $2.4335(0.0026)$ & $2.6893(0.0058)$ & $2.1398(0.0043)$ & $1.7695(0.0011)$ & $1.9822(0.0031)$ & $2.3039(0.0031)$ \\
\hline Immigrant & $0.0772(0.0017)$ & $0.0747(0.0005)$ & $0.0716(0.0008)$ & $0.0788(0.0018)$ & $0.1366(0.0020)$ & $0.0896(0.0005)$ & $0.1120(0.0014)$ & $0.1385(0.0014)$ \\
\hline $\begin{array}{l}\text { Proportion of } \\
\text { undergraduates }\end{array}$ & $0.0157(0.0002)$ & $0.0135(0.0000)$ & $0.0163(0.0001)$ & $0.0171(0.0002)$ & $0.0077(0.0001)$ & $0.0020(0.0000)$ & $0.0067(0.0001)$ & 0.0107 (0.0001) \\
\hline Urbanization rate & $0.0059(0.0000)$ & $0.0075(0.0000)$ & $0.0061(0.0000)$ & $0.0051(0.0001)$ & $0.0052(0.0000)$ & $0.0064(0.0000)$ & $0.0047(0.0000)$ & $0.0035(0.0000)$ \\
\hline Unemployment rate & $0.0061(0.0002)$ & $0.0080(0.0000)$ & $0.0068(0.0001)$ & $0.0056(0.0002)$ & $-0.0149(0.0002)$ & $-0.0220(0.0000)$ & $-0.0106(0.0001)$ & $-0.0087(0.0001)$ \\
\hline \multicolumn{9}{|l|}{$\begin{array}{l}\text { Regions - reference: } \\
\text { Southeast ("Sudeste") }\end{array}$} \\
\hline North ("Norte") & $-0.1088(0.0023)$ & $-0.1452(0.0006)$ & $-0.1289(0.0011)$ & $-0.0598(0.0024)$ & $-0.0097(0.0021)$ & $-0.0233(0.0005)$ & $-0.0393(0.0014)$ & $-0.0034(0.0015)$ \\
\hline Northeast ("Nordeste") & $-0.4521(0.0015)$ & $-0.4601(0.0004)$ & $-0.4536(0.0007)$ & $-0.4238(0.0017)$ & $-0.2243(0.0016)$ & $-0.2302(0.0004)$ & $-0.2084(0.0012)$ & $-0.2163(0.0012)$ \\
\hline South ("Sul") & $0.0388(0.0016)$ & $0.0425(0.0004)$ & $0.0462(0.0007)$ & $0.0547(0.0017)$ & $0.0626(0.0015)$ & $0.0511(0.0004)$ & $0.0785(0.0009)$ & $0.0937(0.0010)$ \\
\hline $\begin{array}{l}\text { Center-West } \\
\text { ("Centro-Oeste") }\end{array}$ & $-0.0113(0.0021)$ & $-0.0386(0.0006)$ & $-0.0222^{\text {ns }}(0.0010)$ & $-0.0022^{\text {ns }}(0.0022)$ & $0.0682(0.0018)$ & $0.0232(0.0005)$ & $0.0466(0.0012)$ & $0.0873(0.0013)$ \\
\hline Constant & $4.6868(0.0032)$ & $4.2149(0.0008)$ & $4.7075(0.0014)$ & $5.1224(0.0033)$ & $5.7699(0.0054)$ & $5.5021(0.0012)$ & $5.8945(0.0033)$ & $6.2193(0.0034)$ \\
\hline Number of observations & $2,160,745$ & & & & $2,155,341$ & & & \\
\hline Adjusted R-squared & 0.4602 & & & & 0.4237 & & & \\
\hline Pseudo R-squared & & 0.2485 & 0.2742 & 0.2991 & & 0.1712 & 0.2197 & 0.2582 \\
\hline
\end{tabular}

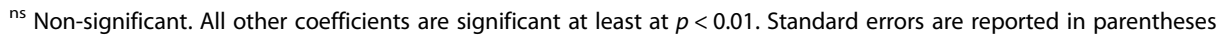

1991, 2000, and 2010 Brazilian Demographic Censuses (IPUMS-International) 
Table 6 Coefficients and standard errors estimated with model from Equation (3) for the logarithm of individual earnings as the dependent variable by income quantile, Mexico, 2000 and 2010

\begin{tabular}{|c|c|c|c|c|c|c|c|c|}
\hline \multirow[t]{2}{*}{ Independent variables } & \multicolumn{4}{|l|}{2000} & \multicolumn{4}{|l|}{2010} \\
\hline & Total & $\begin{array}{l}1 \text { quantile (up to } \\
\text { 25th percentile) }\end{array}$ & $\begin{array}{l}2 \text { quantile (up to } \\
50 \text { th percentile) }\end{array}$ & $\begin{array}{l}3 \text { quantile (above } \\
75 \text { th percentile) }\end{array}$ & Total & $\begin{array}{l}1 \text { quantile (up to } \\
\text { 25th percentile) }\end{array}$ & $\begin{array}{l}2 \text { quantile (up to } \\
50 \text { th percentile) }\end{array}$ & $\begin{array}{l}3 \text { quantile (above } \\
\text { 75th percentile) }\end{array}$ \\
\hline \multicolumn{9}{|c|}{ Age-education groups - reference: $15-24$ years; less than primary completed } \\
\hline $\begin{array}{l}15-24 \text { years; primary } \\
\text { completed }\end{array}$ & $0.0935(0.0031)$ & $0.0844(0.0031)$ & $0.0849(0.0028)$ & $0.0873(0.0035)$ & $0.0943(0.0046)$ & $0.1303(0.0044)$ & $0.0900(0.0034)$ & $0.0781(0.0040)$ \\
\hline $\begin{array}{l}\text { 15-24 years; secondary } \\
\text { completed }\end{array}$ & $0.3263(0.0039)$ & $0.2591(0.0043)$ & $0.2919(0.0038)$ & $0.3644(0.0049)$ & $0.2612(0.0050)$ & $0.2821(0.0051)$ & $0.2201(0.0039)$ & $0.2368(0.0047)$ \\
\hline $\begin{array}{l}\text { 15-24 years; university } \\
\text { completed }\end{array}$ & $0.7675(0.0072)$ & $0.6633(0.0086)$ & $0.7894(0.0077)$ & $0.9212(0.0098)$ & $0.6051(0.0076)$ & $0.5523(0.0098)$ & $0.5838(0.0076)$ & $0.6557(0.0090)$ \\
\hline $\begin{array}{l}25-34 \text { years; less than } \\
\text { primary completed }\end{array}$ & $0.1323(0.0038)$ & $0.0876(0.0038)$ & $0.1028(0.0034)$ & $0.1191(0.0043)$ & $0.1459(0.0054)$ & $0.1070(0.0051)$ & $0.0843(0.0039)$ & $0.0944(0.0047)$ \\
\hline $\begin{array}{l}25-34 \text { years; primary } \\
\text { completed }\end{array}$ & $0.3777(0.0031)$ & $0.3057(0.0031)$ & $0.3103(0.0028)$ & $0.3555(0.0035)$ & $0.3468(0.0046)$ & $0.3597(0.0044)$ & $0.2781(0.0034)$ & $0.2768(0.0040)$ \\
\hline $\begin{array}{l}25-34 \text { years; secondary } \\
\text { completed }\end{array}$ & $0.7553(0.0035)$ & $0.6154(0.0038)$ & $0.6891(0.0034)$ & $0.8236(0.0043)$ & $0.6162(0.0048)$ & $0.5607(0.0049)$ & $0.5122(0.0038)$ & $0.5705(0.0045)$ \\
\hline $\begin{array}{l}25-34 \text { years; university } \\
\text { completed }\end{array}$ & $1.2826(0.0038)$ & $1.1284(0.0042)$ & $1.2552(0.0038)$ & $1.3990(0.0048)$ & $1.0334(0.0050)$ & $0.9320(0.0055)$ & $0.9363(0.0042)$ & $1.0232(0.0050)$ \\
\hline $\begin{array}{l}35-49 \text { years; less than } \\
\text { primary completed }\end{array}$ & $0.1599(0.0034)$ & $0.0755(0.0034)$ & $0.1030(0.0030)$ & $0.1426(0.0038)$ & $0.1697(0.0049)$ & $0.0975(0.0047)$ & $0.0874(0.0036)$ & $0.1267(0.0043)$ \\
\hline $\begin{array}{l}35-49 \text { years; primary } \\
\text { completed }\end{array}$ & $0.4637(0.0031)$ & $0.3414(0.0032)$ & $0.3681(0.0029)$ & $0.4689(0.0036)$ & $0.4248(0.0045)$ & $0.3812(0.0043)$ & $0.3287(0.0034)$ & $0.3683(0.0040)$ \\
\hline $\begin{array}{l}35-49 \text { years; secondary } \\
\text { completed }\end{array}$ & $0.9608(0.0036)$ & $0.7621(0.0040)$ & $0.9080(0.0036)$ & $1.1029(0.0045)$ & $0.7826(0.0048)$ & $0.6648(0.0049)$ & $0.6675(0.0038)$ & $0.7774(0.0045)$ \\
\hline $\begin{array}{l}\text { 35-49 years; university } \\
\text { completed }\end{array}$ & $1.5244(0.0036)$ & $1.3490(0.0039)$ & $1.5047(0.0035)$ & $1.6709(0.0045)$ & $1.3167(0.0049)$ & $1.1680(0.0053)$ & $1.2096(0.0041)$ & $1.3684(0.0049)$ \\
\hline
\end{tabular}


Table 6 Coefficients and standard errors estimated with model from Equation (3) for the logarithm of individual earnings as the dependent variable by income quantile, Mexico, 2000 and 2010 (Continued)

\begin{tabular}{|c|c|c|c|c|c|c|c|c|}
\hline $\begin{array}{l}\text { 50-64 years; less than } \\
\text { primary completed }\end{array}$ & $0.0572(0.0035)$ & $-0.0342(0.0035)$ & $0.0000(0.0032)$ & $0.0462(0.0040)$ & $0.0589(0.0049)$ & $-0.0511(0.0047)$ & $-0.0160(0.0036)$ & $0.0395(0.0043)$ \\
\hline $\begin{array}{l}\text { 50-64 years; primary } \\
\text { completed }\end{array}$ & $0.4209(0.0037)$ & $0.2502(0.0040)$ & $0.3136(0.0036)$ & $0.4679(0.0045)$ & $0.3770(0.0048)$ & $0.2822(0.0047)$ & $0.2784(0.0037)$ & $0.3654(0.0044)$ \\
\hline $\begin{array}{l}\text { 50-64 years; secondary } \\
\text { completed }\end{array}$ & $1.0744(0.0058)$ & $0.8096(0.0068)$ & $1.0394(0.0061)$ & $1.3284(0.0078)$ & $0.8150(0.0055)$ & $0.6433(0.0064)$ & $0.7161(0.0050)$ & $0.9009(0.0060)$ \\
\hline $\begin{array}{l}\text { 50-64 years; university } \\
\text { completed }\end{array}$ & $1.6605(0.0052)$ & $1.4489(0.0060)$ & $1.6866(0.0054)$ & $1.9154(0.0068)$ & $1.3988(0.0054)$ & $1.1799(0.0064)$ & $1.3282(0.0050)$ & $1.5311(0.0060)$ \\
\hline Immigrant & $0.1387(0.0017)$ & $0.1243(0.0019)$ & $0.1294(0.0017)$ & $0.1454(0.0022)$ & $0.1479(0.0017)$ & $0.1327(0.0021)$ & $0.1263(0.0016)$ & $0.1380(0.0019)$ \\
\hline $\begin{array}{l}\text { Proportion of } \\
\text { undergraduates }\end{array}$ & $0.0058(0.0001)$ & $0.0060(0.0001)$ & $0.0073(0.0001)$ & $0.0099(0.0001)$ & $0.0082(0.0001)$ & $0.0132(0.0002)$ & $0.0135(0.0001)$ & $0.0140(0.0001)$ \\
\hline Urbanization rate & $0.0052(0.0000)$ & $0.0044(0.0000)$ & $0.0035(0.0000)$ & $0.0030(0.0000)$ & $0.0038(0.0000)$ & $0.0037(0.0000)$ & $0.0025(0.0000)$ & $0.0023(0.0000)$ \\
\hline Unemployment rate & $-0.0144(0.0009)$ & $-0.0004^{\text {ns }}(0.0008)$ & $-0.0007^{\text {ns }}(0.0007)$ & $-0.0026(0.0009)$ & $0.0012(0.0005)$ & $0.0066(0.0004)$ & $0.0067(0.0003)$ & $0.0053(0.0003)$ \\
\hline \multicolumn{9}{|l|}{$\begin{array}{l}\text { Regions - reference: } \\
\text { Northeast ("Nordeste") }\end{array}$} \\
\hline Northwest ("Noroeste") & $0.1166(0.0020)$ & $0.0900(0.0024)$ & $0.1049(0.0022)$ & $0.1393(0.0027)$ & $0.1035(0.0021)$ & $0.0142(0.0030)$ & $0.0252(0.0023)$ & $0.0369(0.0028)$ \\
\hline West ("Ocidente") & $0.0014^{\text {ns }}(0.0019)$ & $0.0247(0.0022)$ & $0.0342(0.0019)$ & $0.0309(0.0025)$ & $0.0850(0.0020)$ & $0.0336(0.0026)$ & $0.0503(0.0020)$ & $0.0342(0.0024)$ \\
\hline East ("Oriente") & $-0.2247(0.0017)$ & $-0.2860(0.0018)$ & $-0.2442(0.0017)$ & $-0.2314(0.0021)$ & $-0.1487(0.0020)$ & $-0.2693(0.0024)$ & $-0.2260(0.0018)$ & $-0.2055(0.0022)$ \\
\hline $\begin{array}{l}\text { Center-North } \\
\text { ("Centro-Norte") }\end{array}$ & $0.0200(0.0020)$ & $-0.0255(0.0023)$ & $-0.0010^{\text {ns }}(0.0020)$ & $0.00628(0.0026)$ & $0.0108(0.0021)$ & $-0.0776(0.0028)$ & $-0.0641(0.0022)$ & $-0.0630(0.0026)$ \\
\hline $\begin{array}{l}\text { Center-South } \\
\text { ("Centro-Sul") }\end{array}$ & $-0.1013(0.0015)$ & $-0.1081(0.0018)$ & $-0.1012(0.0016)$ & $-0.1015(0.0020)$ & $-0.0411(0.0017)$ & $-0.1195(0.0025)$ & $-0.0800(0.0019)$ & $-0.0670(0.0023)$ \\
\hline Southeast ("Sudeste") & $-0.2511(0.0025)$ & $-0.3598(0.0027)$ & $-0.2868(0.0024)$ & $-0.2378(0.0031)$ & $-0.0541(0.0026)$ & $-0.2258(0.0031)$ & $-0.1800(0.0024)$ & $-0.1487(0.0028)$ \\
\hline Southwest ("Sudoeste") & $-0.2861(0.0021)$ & $-0.3111(0.0022)$ & $-0.2122(0.0019)$ & $-0.1413(0.0025)$ & $-0.2473(0.0024)$ & $-0.3880(0.0026)$ & $-0.2662(0.0020)$ & $-0.1919(0.0024)$ \\
\hline
\end{tabular}


Table 6 Coefficients and standard errors estimated with model from Equation (3) for the logarithm of individual earnings as the dependent variable by income quantile, Mexico, 2000 and 2010 (Continued)

\begin{tabular}{|c|c|c|c|c|c|c|c|c|}
\hline Constant & $6.9452(0.0036)$ & $6.7441(0.0034)$ & $7.0710(0.0031)$ & $7.3596(0.0039)$ & $7.6936(0.0051)$ & $7.4102(0.0049)$ & $7.8288(0.0037)$ & $8.1385(0.0045)$ \\
\hline Number of observations & $1,733,662$ & & & & $1,900,671$ & & & \\
\hline Adjusted R-squared & 0.3858 & & & & 0.2761 & & & \\
\hline Pseudo R-squared & & 0.2099 & 0.2407 & 0.2755 & & 0.1484 & 0.1584 & 0.1902 \\
\hline
\end{tabular}

${ }^{n s}$ Non-significant. All other coefficients are significant at least at $p<0.05$. Standard errors are reported in parentheses

1991, 2000, and 2010 Brazilian Demographic Censuses (IPUMS-International) 


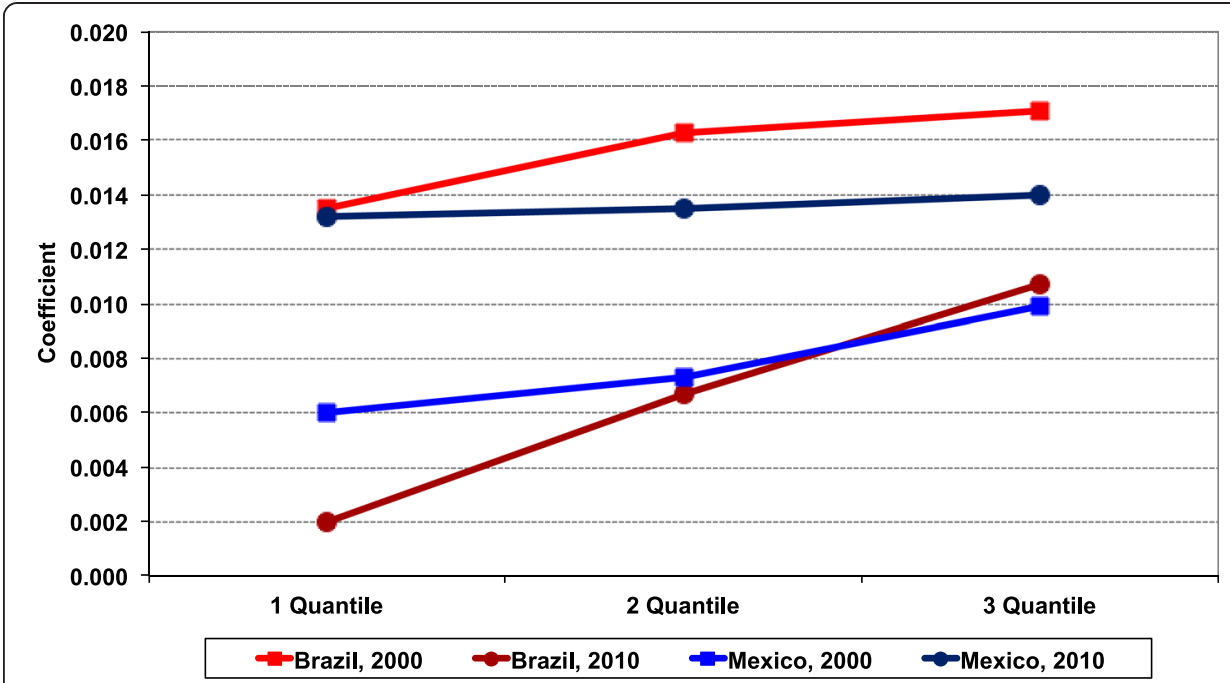

Fig. 3 Coefficients of predicted proportion of undergraduates (from Tables 5 and 6) for the logarithm of individual earnings as the dependent variable by income quantile, Brazil and Mexico, 2000 and 2010. Source: Brazilian and Mexican Demographic Censuses (IPUMS-International)

\section{Conclusions}

The advance of this study beyond the preceding literature is the inclusion of the ageeducation cell sizes (proportion of males in each age-education group, cohort size, relative supply, labor supply, cell density, or own-quantity effects) into the models. Estimations suggest that changes in the composition of the workforce are associated with levels of earnings. The proportion of people in age-education groups tends to have a negative correlation with earnings, with greater effects for people with secondary completed, even when compared to workers with university completed. These results are consistent with previous studies, which indicate that age-education groups are not perfect substitutes, generating negative associations of cohort size with workers' income. We also know that there are higher proportions of men in groups with secondary completed than in university completed. These results are an indicative that labor markets are requiring workers with higher qualifications (university) than with mid-level qualifications (secondary). These models capture two sets of disadvantage for workers with secondary completed: (a) they already have lower levels of earnings than those with university completed, as it is indicated by age-education indicators from Equations (1) and (2); and (b) they compete with a bigger cohort in the labor markets, which depreciates even further their earnings, as it is suggested by the effects of proportions in ageeducation groups from Equation (2). There has been an increase in the demand for high-educated workers in Brazil and Mexico during recent decades, which decreases the negative effects of the supply of workers with secondary or university completed over time. For Mexico, the decrease in the proportion of the young population over time and the supply of people with higher levels of educational attainment is smaller in magnitude than in Brazil. These slower changes might be a reason of cohort-size elasticities with smaller scales in Mexico.

We also find that the concentration of skilled workers, in recent years, is related to higher returns to schooling. This pattern is not surprising since regional differences for both countries are well known. The existence of these differences is sustained by labor 
market conditions, which are produced and appear to be maintained by the process of regional economic development. We found that there are social effects of human capital, i.e., locations with higher average human capital have higher levels of earnings and lower private rates of return to formal education. Results indicate positive and significant associations of proportion of undergraduates with workers' earnings across the income distribution. The concentration of human capital in specific regions generates benefits for the entire set of resident workers in the region. Even the less productive workers observe positive effects on their productivity and earnings. We argue that these effects are a result of the characteristics of the labor markets in Brazil and Mexico. Since the percentage of workers with higher education (university completed) is still small, labor markets face two effects in opposite directions. On one side, there is a complementary effect, because more educated workers could benefit others with the same and lower levels of education by increasing overall productivity levels. On the other side, least-educated workers - a large share of labor force - compete with each other in the labor market and could be considered substitutes to each other, thus depressing wages. In the case of less developed economies, the negative effects are surpassing the positive ones.

This paper finds that that the concentration of skilled workers is associated with higher average earnings. We verified that poorer and more unequal countries (such as Brazil and Mexico) have much stronger correlations than the ones observed in more developed countries (Moretti 2004a, Moretti 2004b, Moretti 2004c). We estimated significant social effects of human capital concentration with earnings, which has been decreasing over time in Brazil and increasing in Mexico. The geographical concentration of human capital benefits the entire set of resident workers in the region -- even the least productive workers observe a positive effect on their earnings. Brazilian workers in the highest quantile of the income distribution have higher correlations between human capital concentration and earnings than workers in lowest quantiles. These differentials are not so pronounced in Mexico. The existence of these differences is sustained by the conditions of local labor markets in Brazil and Mexico, which have developed regions coexisting with regions still under development. The conditions of labor markets were produced and appear to be maintained by regional economic development processes.

These overall results suggest that educational improvements are essential to increase earnings of workers. Public policies aiming to increase the proportion of people with completed university education should continue to be implemented in these countries. Examples of these policies are the expansion of public universities, provision of scholarships and student loans to economically disadvantaged students to attend undergraduate programs, and affirmative actions to increase the proportion of underrepresented socioeconomic groups in the university. 
B.L.Q. is an Associate Professor at the Universidade Federal de Minas Gerais (UFMG) in Brazil and the coordinator of the Latin America Human Mortality Database. He has research experience in demography, especially in topics related to labor markets, population ageing, social security systems, retirement, adult mortality, and demographic methods. J.A.C. is a researcher at the Center for Regional Development and Planning (CEDEPLAR) of the Universidade Federal de Minas Gerais (UFMG) in Brazil. She has been working on projects related to labor markets, demographic transitions, and public health.

\section{Acknowledgements}

This manuscript is part of the research project "Demographic transition, labor market, and concentration of highly skilled workers in developing countries" funded by the Minas Gerais Research Support Foundation, Brazil (FAPEMIG) (CSA 01802-13 APQ) and the Brazilian Ministry of Science, Technology, and Innovation (CNPq/MCTI) (474156/2013-3). We gratefully acknowledge helpful comments received from the referee of this journal. Responsible editor: David Lam

\section{Author details}

${ }^{1}$ RAND Corporation, 1776 Main Street, P.O. Box 2138, Santa Monica, CA 90407-2138, USA. ${ }^{2}$ Universidade Federal de Minas Gerais, Av. Antônio Carlos, 6627, FACE 3014, Belo Horizonte, MG 31270-901, Brazil.

Received: 29 April 2015 Accepted: 15 October 2015

Published online: 29 December 2015

\section{References}

Acemoglu DA (1996) Microfundation for social increasing returns in human capital. Q J Econ 111:779-804

Amaral EFL (2012) The decomposition of economic outcomes as a result of changes in Brazil's male age-education structure. Popul Res Policy Rev 31(6):883-905

Amaral EFL, Rios-Neto ELG, Potter JE. 2016 (forthcoming). The influence of internal migration on male earnings in Brazil, 1970-2000. Migration and Development (http://dx.doi.org/10.1080/21632324.2015.1038010).

Amaral EFL, Rios-Neto ELG, Potter JE (2012) Long term influences of age-education transition on the Brazilian labour market. Bull Lat Am Res 31(3):302-319

Amaral EFL, Almeida ME, Rios-Neto ELG, Potter JE (2013a) Effects of the age-education structure of female workers on male earnings in Brazil. Poverty Public Policy 5(4):336-353

Amaral EFL, Potter JE, Hamermesh DS, Rios-Neto ELG (2013b) Age, education and earnings in the course of Brazilian development: does composition matter? Demogr Res 28(20):581-612

Barro RJ, Lee JW (2001) International data on educational attainment: Updates and implications. Oxf Econ Pap 53(3):541-563

Berger M (1985) The effect of cohort size on earnings growth: a reexamination of the evidence. J Polit Econ 93(3):561-573

Berry C, Glaeser E (2005) The divergence of human capital levels across cities. Pap Reg Sci 84(3):407-444

Biagi F, Lucifora C (2008) Demographic and education effects on unemployment in Europe. Labour Econ 15:1076-1101

Black D. 1999. Local knowledge spillovers and inequality. In ERSA conference papers: ersa99pa409. European Regional Science Association. (http://www-sre.wu-wien.ac.at/ersa/ersaconfs/ersa99/Papers/A409.PDF)

Borjas GJ (2003) The labor demand curve is downward sloping: Reexamining the impact of immigration on the labor market. Q J Econ 118:1335-1374

Brunello G (2010) The effects of cohort size on European earnings. J Popul Econ 23:273-290

Despa S (2007) Quantile Regression. Cornell University, Cornell Statistical Consulting, StatNews 70 (https:// www.cscu.cornell.edu/news/statnews/stnews70.pdf)

Easterlin RA (1978) What will 1984 be like? Socioeconomic implications of recent twists in age structure. Demography 15(4):397-432

Freeman RB (1979) The effect of demographic factors on age-earnings profiles. J Hum Resour 14(3):289-318

Gong X, Van Soest A (2002) Wage differentials and mobility in the urban labour market: A panel data analysis for Mexico. Labour Econ 9(4):513-529

Hamermesh D (1993) Labor demand. Princeton University Press, Princeton

Hout M (2012) Social and economic returns to college education in the United States. Annu Rev Sociol 38:379-400

Katz LF, Autor DH (1999) Changes in the wage structure and earnings inequality. In: Ashenfelter O, Card D (eds) Handbook of Labor Economics, vol 3, Part 1. North-Holland, Amsterdam, pp 1463-1555

Katz LF, Murphy KM (1992) Changes in relative wages, 1963-1987: supply and demand factors. Q J Econ 107(1):35-78 Korenman S, Neumark D (2000) Cohort crowding and youth labor markets: a cross-sectional analysis. In: Blanchflower D, Freeman R (eds) Youth Employment and Joblessness in Advanced Countries. NBER Chicago University Press, Chicago, pp 57-105

Lam D, Marteleto L (2005) Small families and large cohorts: The impact of the demographic transition on schooling in Brazil. In: Lloyd CB, Behrman JR, Stromquist NP, Cohen B (eds) The Changing Transitions to Adulthood in Developing Countries: Selected Studies. The National Academies Press, Washington, DC, pp 56-83

Lam D, Marteleto L (2008) Stages of the demographic transition from a child's perspective: Family size, cohort size, and children's resources. Popul Dev Rev 34(2):225-252

Lustig N, Lopez-Calva L, Ortiz-Juarez E (2013) Declining inequality in Latin America in the 2000s: The cases of Argentina, Brazil, and Mexico. World Dev 44:129-141

Marcílio ML (2001) Why are Brazil's public schools so weak? Backwardness in education. Braudel Papers 30:3-11

Marcílio ML (2005) História da Escola em São Paulo e no Brasil. Imprensa Oficial do Estado, São Paulo

Martins PS, Pereira PT (2004) Does education reduce wage inequality? Quantile regression evidence from 16 countries. Labour Econ 11:355-371

Mincer J (1974) Schooling, Experience, and Earnings. National Bureau of Economic Research (NBER), New York 
Moretti E (2004a) Estimating the social return to higher education: Evidence from longitudinal and repeated crosssectional data. J Econ 121:175-212

Moretti E (2004b) Human capital externalities in cities. In: Henderson JV, Thisse J-F (eds) Handbook of Urban and Regional Economics, vol 4. North-Holland, Amsterdam, pp 2063-3073

Moretti E (2004c) Workers' education, spillovers, and productivity: Evidence from plant-level production functions. Am Econ Rev 94(3):656-690

Moretti E (2011) Local labor markets. In: Ashenfelter O, Card D (eds) Handbook of Labor Economics, vol 4, Part B. NorthHolland, Amsterdam, pp 1237-1313

Potter JE, Schmertmann CP, Cavenaghi SM (2002) Fertility and development: evidence from Brazil. Demography 39(4):739-761

Potter JE, Schmertmann CP, Assunção RM, Cavenaghi SM (2010) Mapping the timing, pace, and scale of the fertility transition in Brazil. Popul Dev Rev 36(2):283-307

Queiroz BL, Calazans JA (2010) Os efeitos da concentração de capital humano no retorno privado e social da educaçao no Brasil. Paper presented at the XVII Encontro Nacional de Estudos Populacionais. Caxambu, Brazil

Queiroz BL, Golgher AB (2008) Human capital differentials across municipalities and states in Brazil. Popul Rev 47(2):25-49

Rauch JE (1993) Productivity gains from geographic concentration of human capital: Evidence from cities. J Urban Econ 34:380-400

Riani JLR (2005) Determinantes do resultado educacional no Brasil: Família, perfil escolar dos municípios e dividendo demográfico numa abordagem hierárquica e espacial. Universidade Federal de Minas Gerais (UFMG), Belo Horizonte

Rios-Neto ELG, Guimarães RRM (2010) The demography of education in Brazil: Inequality of educational opportunities based on grade progression probability (1986-2008). Vienna Yearbook Popul Res 8(1):283-312

Sapozhnikov M, Triest RK (2007) Population aging, labor demand, and the structure of wages, Work Opportunities for Older Americans Series Working Paper 8

Shimer R (2001) The impact of young workers on the aggregate labor market. Q J Econ 116(3):969-1007

Skans ON (2005) Age effects in Swedish local labor markets. Econ Lett 86:419-426

Welch F (1979) Effects of cohort size on earnings: the baby boom babies' financial bust. J Polit Econ 87(5, Part 2):S65-S97

\section{Submit your manuscript to a SpringerOpen ${ }^{\circ}$ journal and benefit from:}

- Convenient online submission

- Rigorous peer review

- Immediate publication on acceptance

- Open access: articles freely available online

- High visibility within the field

Retaining the copyright to your article 